\title{
ULTRAFILTRATION: BOON OR BANE?
}

\author{
C M Hüls ${ }^{1} \cdot$ P M Grootes $\bullet$ M-J Nadeau \\ Leibniz-Laboratory for Radiometric Dating and Isotope Research, Christian-Albrechts-University, Kiel, Germany.
}

ABSTRACT. Ultrafiltration of bone collagen, dissolved as gelatin ( $\mathrm{M} 100,000 \mathrm{D})$, has received considerable attention as a means to remove small contaminants and thus produce more reliable dates (Brown et al. 1988; Bronk Ramsey et al. 2004; Higham et al. 2006; Mellars 2006). However, comparative dating studies have raised the question whether this cleaning step itself may introduce contamination with carbon from the filters used (Bronk Ramsey et al. 2004; Brock et al. 2007; Hüls et al. 2007).

Here, we present results of further ultrafiltration experiments with modern and fossil collagen samples using Vivaspin $20^{\mathrm{TM}}$ and Vivaspin $15 \mathrm{R}^{\mathrm{TM}}$ ultrafilters. Evidently, the Vivaspin 20 (VS 20) ultrafilter with a polyethersulfone (PES) membrane retains more material in the $>30 \mathrm{kD}$ fraction than the Vivaspin $15 \mathrm{R}$ (VS 15R) filter with a regenerated cellulose membrane (Hydrosat), which may be related to increased retention of proteins due to suboptimal electrostatic conditions during ultrafiltration with the PES membrane. In addition, this filter type shows clear evidence for contamination with fossil carbon, presumably from membrane fibers, in the $<30 \mathrm{kD}$ fraction. Radiocarbon measurements on ultrafiltrated fossil collagen seem to indicate small contributions of modern carbon via glycerin left on and within the filter membranes of both types. Although SEM pictures show film remnants on the fibrous filter structure of cleaned filter membranes, EDX analysis on the VS 20 membrane to not support the assumption this may be glycerin. Our observations indicate the risks and benefits of the use of ultrafiltration in cleaning collagen samples for ${ }^{14} \mathrm{C}$ dating need to be further quantified, especially for the cleaning of fossil bone collagen of good quality samples.

\section{INTRODUCTION}

The radiocarbon dating of bones is usually performed on the collagen fraction, which is purified by dissolution from the demineralized bone as gelatin in hot acidic water (hydrolysis, e.g. Longin 1970). However, this procedure will also include other hot-water-soluble components such as humics and degraded protein fragments (from exogenous sources, such as soil amino acids, or endogenous by formation from collagen) (van Klinken and Mook 1990). Adding an alkali extraction of the demineralized bone material helps to remove alkali-soluble organics such as humic acid (van Klinken and Hedges 1995). In addition, ultrafiltration (UF) has been suggested as an effective method to remove low-molecular weight contaminants and degraded proteins from the high-molecular and unchanged proteins of the collagen (e.g. Brown et al. 1988; Bronk Ramsey et al. 2004). However, unlike the classical sieving process, the separation between smaller and larger particles also depends on the charge state of the membrane and the proteins, and can even be reversed (e.g. Gosh 2003; Wang and Rodgers 2005; Burns and Zydney 1999).

The UF cleaning method for extracted fossil collagen has received considerable attention (e.g. Mellars 2006), as it was shown that redating previously dated bones using UF and modern bone pretreatment resulted in many cases in ${ }^{14} \mathrm{C}$ ages that were significant older and more consistent (e.g. Bronk Ramsey 2004; Higham et al. 2006). However, comparative dating studies also found evidence for contamination introduced by the filters used (Bronk Ramsey et al. 2004; Brock et al. 2007; Hüls et al. 2007).

Here, we present further results of ultrafiltration tests using modern and fossil bone collagen, industrial collagen, and 2 different UF-membrane types, with a focus on the performance of the 2 membranes with regard to the partitioning of the solution over filtrate and retentate and the effect of filtering on the ${ }^{14} \mathrm{C}$ content of these fractions.

\footnotetext{
${ }^{1}$ Corresponding author. Email: mhuels@leibniz.uni-kiel.de.
}

(C) 2009 by the Arizona Board of Regents on behalf of the University of Arizona Proceedings of the 5th International ${ }^{14} \mathrm{C}$ and Archaeology Symposium, edited by Irka Hajdas et al. RADIOCARBON, Vol 51, Nr 2, 2009, p 613-625 


\section{MATERIAL AND METHODS}

The details of the 2 filters, Vivaspin $20^{\mathrm{TM}}$ (VS 20, a polyethersulfone membrane, PES) and Vivaspin $15 \mathrm{R}^{\mathrm{TM}}$ (VS 15R, a regenerated cellulose membrane, Hydrosat), both with a molecular weight cut-off (MWCO) of 30,000 Dalton (D), as well as their cleaning and use have been described in a previous paper by Hüls et al. (2007). They also showed that the VS 20 membrane has a ${ }^{14} \mathrm{C}$ content of $0.54 \pm$ $0.09 \mathrm{pMC}$, while VS $15 \mathrm{R}$ shows values between $14.36 \pm 0.11$ and $17.48 \pm 0.15 \mathrm{pMC}$. Thus, both membranes consist mainly of fossil carbon. The membranes have been coated with glycerin to keep the filters flexible. Before 2005, this glycerin contained fossil carbon, and now contains modern carbon (Brock et al. 2007). A modern carbon source was confirmed by ${ }^{14} \mathrm{C}$ measurements of the glycerin used (courtesy of Vivascience) and of samples taken from the cleaning water of the filters (glycerin: $107 \pm 0.35 \mathrm{pMC}$; cleaning water step $1>30 \mathrm{kD}: 108.30 \pm 0.38 \mathrm{pMC}$; $<30 \mathrm{kD}: 108.08 \pm 0.33$ pMC and $106.94 \pm 0.32 \mathrm{pMC}$; Hüls et al. 2007). To avoid sample contamination, we remove the glycerin from the filter membranes by repeated washing and ultrasonication with ultra-pure water in a cleaning procedure based on Bronk Ramsey et al. (2004), described in Hüls et al. (2007). Comparison of ${ }^{14} \mathrm{C}$ contents before and after filtering indicates the procedure is adequate for the removal of the humectants (Hüls et al. 2007).

For a visual inspection of the cleaning, we took scanning electron microscope (SEM) pictures of original and cleaned membranes of the 2 ultrafilters VS 20 and VS 15R (Figure 1). The untreated filter membranes (VS 20 and VS 15R) show a coating, which we assumed at first to be glycerin, on and in between the fibers of either PES or Hydrosat (Figure 1A and D). Remnants of this coating are still visible in the cleaned filter membranes (Figure 1B and E). A more rigorous cleaning, including methanol, still left flakes of the coating (Figure 1C and F). Energy dispersive X-ray spectroscopy (EDX) on VS 20 membranes (original and cleaned), however, indicates the flakes are composed of PES and are thus an artifact of the manufacture of this membrane. A similar measurement for the VS $15 \mathrm{R}$ membrane is possible but will not give conclusive results, since membrane and humectant contain largely similar elements with only minor differences in the carbon to oxygen ratio.

Both tested ultrafilters contain both fossil and modern carbon. We therefore tested for residual contamination caused by the cleaned filters by ultrafiltration of 2 modern and 2 archaeological collagen samples. The modern materials are an industrially produced collagen from porcine dermis (MBP Medical Biomaterial Products, Hüls et al. 2007) and collagen extracted from a bovine bone acquired in 2006. The old collagen was obtained from 2 Paleolithic bones from caves in the Swabian Jura, using our standard modified Longin procedures (Longin 1970; Grootes et al. 2004; Hüls et al. 2007).

The ultrafiltration tests were performed on the lyophilized collagen fractions of the pig skin and the 1 modern and 2 fossil bones, dissolved in ultra-clean water (VS 20: $20 \mathrm{~mL}$; VS 15R: $15 \mathrm{~mL}$ ) and then centrifuged at $3000 \mathrm{rpm}$ until $1-2 \mathrm{~mL}$ is left above the ultrafilter. Starting weights for ultrafiltration of modern collagen of 10,30, and $80 \mathrm{mg}$ were used to test for any effect of collagen concentration on recovery, partition between filtrate and retentate, and ${ }^{14} \mathrm{C}$ concentration. The 2 fossil collagen samples were filtered using $50 \mathrm{mg}$. In addition to the single filtration experiment $\left(1^{*}\right.$ filtration), modern collagen was subjected to a double filtration ( $2 *$ filtration), e.g. first filtration down to $1-2 \mathrm{~mL}$ in the retentate, removal of the filtrate, refilling of the ultrafilter and the supernatant with ultra-pure water, and a subsequent 2 nd filtration down to $1-2 \mathrm{~mL}$ in the $>30 \mathrm{kD}$ fraction.

Both UF fractions, the retentate ( $>30 \mathrm{kD})$ and the filtrate $(<30 \mathrm{kD})$, were lyophilized and weighed. Both freeze-dried ultrafiltered collagen fractions (UF col $>30 \mathrm{kD}$ and $<30 \mathrm{kD}$ ) and the original collagen (Lcol) were burnt to $\mathrm{CO}_{2}$, graphitized, and measured at the Leibniz-Labor AMS system using standard procedures (Nadeau et al. 1997, 1998). 


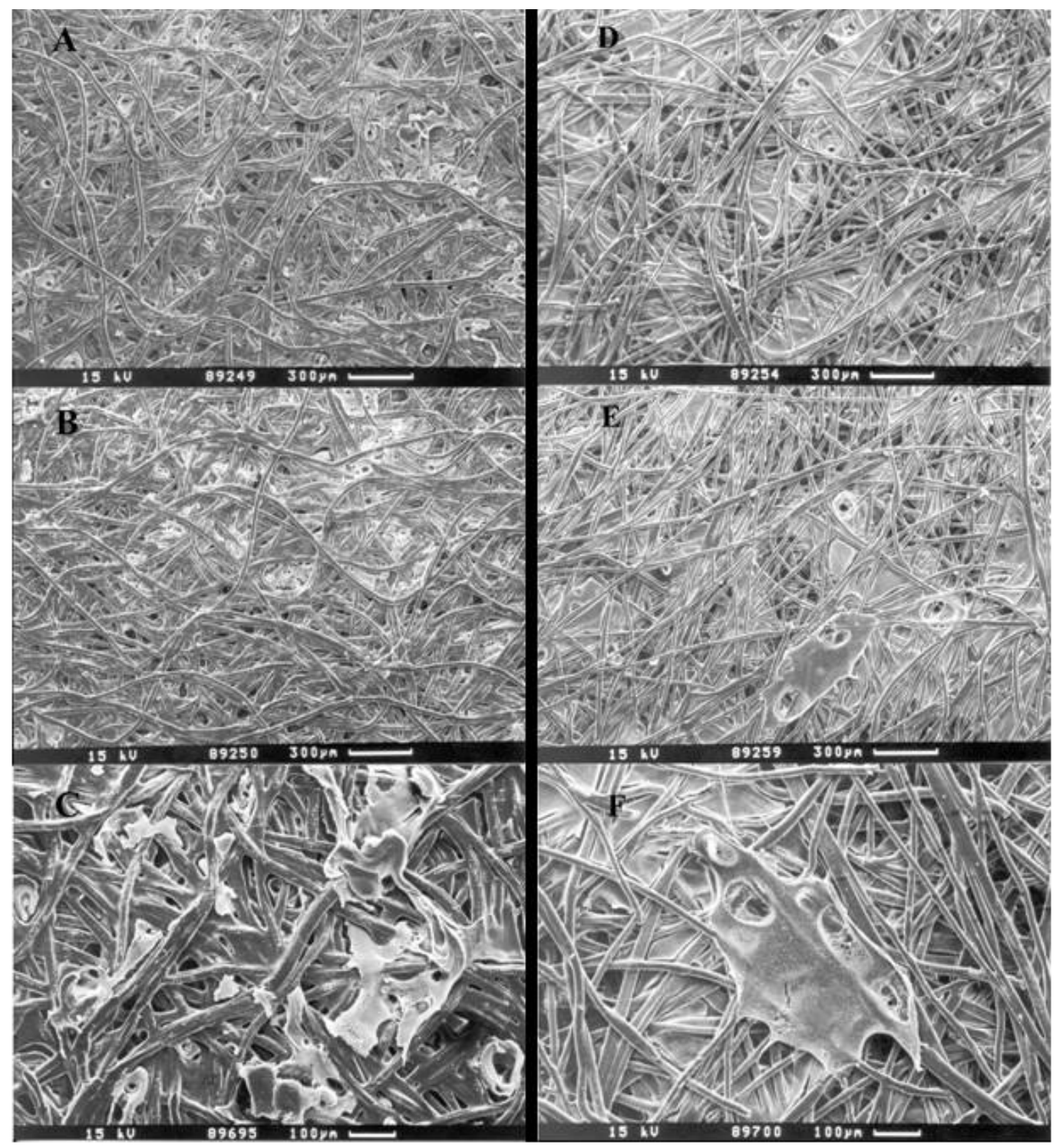

Figure 1 A-C: SEM of membrane VS 20 (polyethersulfone), A) original, uncleaned membrane, B) cleaned after step 3, C) cleaned in addition with MeOH. D-F: SEM of membrane VS 15R (regenerated cellulose), A) original, uncleaned membrane, B) cleaned after step 3, C) cleaned in addition with $\mathrm{MeOH}$.

\section{RESULTS}

\section{Radiocarbon Measurements on Modern Ultrafiltered Collagen}

To test for possible old filter contaminants, we used 2 modern collagen samples that we subjected to a single filtration and to a double filtration. Sample KIA 29425 is an industrially produced collagen from pig skin, which is used as a raw material for bioresorbable wound dressings. The sample material consists of a dried, white powder and was acquired in 2006 . The measured ${ }^{14} \mathrm{C}$ content is $107.39 \pm 0.33$ pMC $\left(\delta^{13} \mathrm{C}:-20.41 \pm 0.13 \%\right.$ o), which is equivalent with an atmospheric ${ }^{14} \mathrm{C}$ around 
2003 (Levin and Kromer 2004; Levin and Kromer, personal communication, 2006). Depending on the homogeneity of the raw material (age of the pigs of which skins were used is assumed to be $\sim 6$ months) and diet of the animal, the variability in ${ }^{14} \mathrm{C}$ content may be assumed to be $\leq 1 \mathrm{pMC}$.

Sample KIA 30242 is collagen, extracted in the Leibniz Laboratory from a bovine bone acquired in 2006 . The ${ }^{14} \mathrm{C}$ content measured on the unfiltered collagen (Lcol) is $106.21 \pm 0.29 \mathrm{pMC}\left(\delta^{13} \mathrm{C}\right.$ : $-13.45 \pm 0.17 \%$ ), equivalent with an atmospheric ${ }^{14} \mathrm{C}$ between 2003 and 2005 (Levin and Kromer, personal communication, 2006). The remaining non-soluble bone gave a ${ }^{14} \mathrm{C}$ concentration of $106.30 \pm 0.3 \mathrm{pMC}\left(\delta^{13} \mathrm{C}:-16.05 \pm 0.13 \%\right.$ ) , well within $1 \sigma$ of the collagen ${ }^{14} \mathrm{C}$. Based on these results, we assume a rather homogenous ${ }^{14} \mathrm{C}$ distribution within the extracted collagen.

\section{Modern Industrial Collagen (KIA 29425)}

The results for the single and double ultrafiltration experiments for both filter membranes are summarized in Table 1 and illustrated in Figure 2.

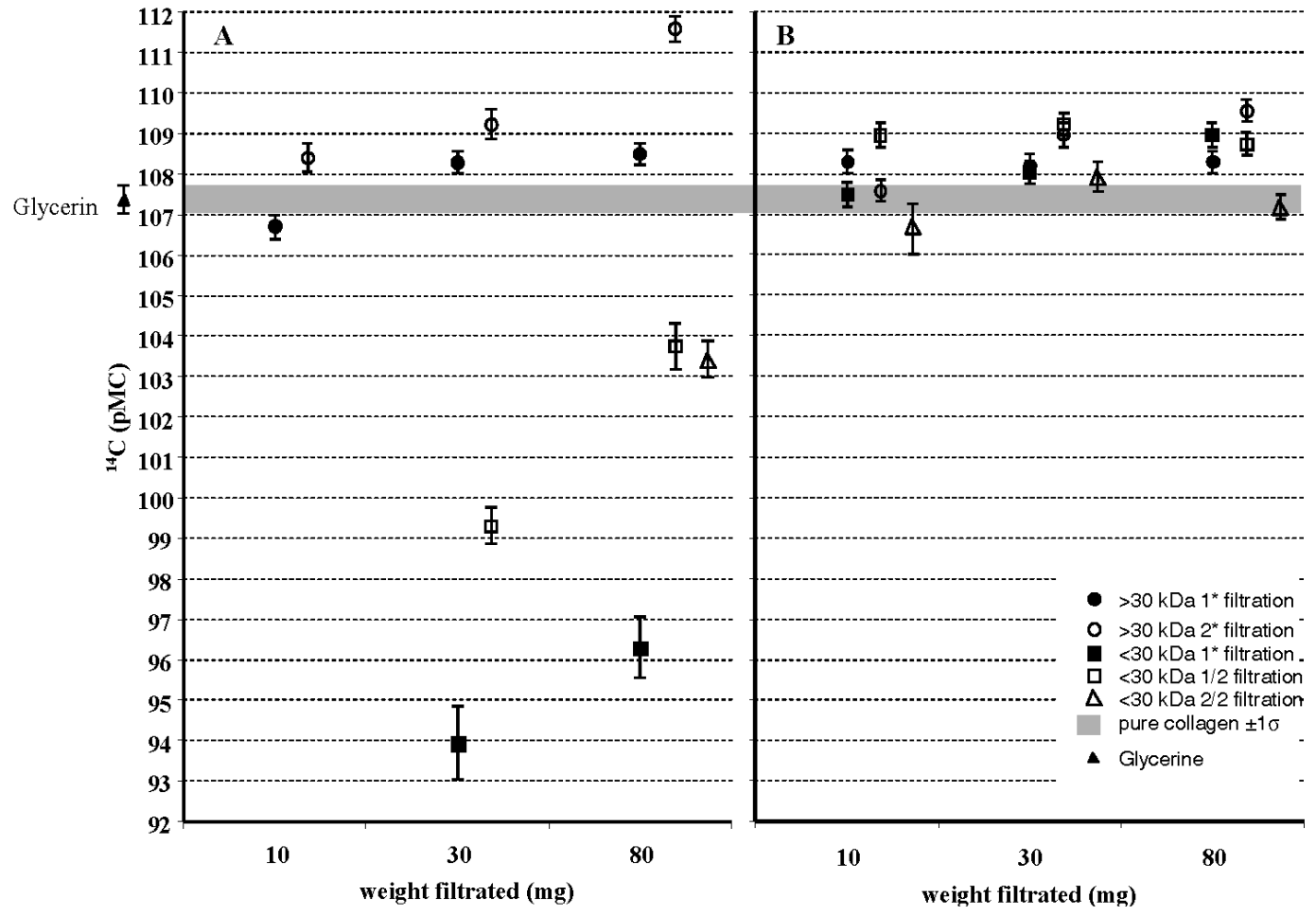

Figure 2 Ultrafiltration of modern industrial collagen (KIA 29425): A) Vivaspin 20 (PES); B) Vivaspin 15R (Hydrosat).

\section{VS 20 (PES)}

The recovery of the single and double filtration with VS 20 ultrafilters is between 75 and 90\%, with some variability during the double filtration experiment (see Table 1). The $>30 \mathrm{kD}$ fraction (retentate) generally contains more than $90 \mathrm{wt} \%(92.7-100 \mathrm{wt} \%)$ of the recovered material, indicating a collagen sample that contains mostly high-molecular proteins $>30 \mathrm{kD}$. 
Table $1{ }^{14} \mathrm{C}$ measurements of modern industrial collagen of KIA $29425\left({ }^{14} \mathrm{C}: 107.39 \pm 0.3 \mathrm{pMC}\right.$, $\delta^{13} \mathrm{C}:-20.41 \pm 0.13 \%$ )

\begin{tabular}{|c|c|c|c|c|c|c|}
\hline Membrane & $\begin{array}{l}\text { Weight } \\
(\mathrm{mg})\end{array}$ & $\begin{array}{l}\text { Recovery } \\
(\%)\end{array}$ & Size & wt $\%$ & $\mathrm{pMC}$ & $\delta^{13} \mathrm{C}(\% o)^{\mathrm{a}}$ \\
\hline \multicolumn{7}{|c|}{$1 *$ Ultrafiltration } \\
\hline \multirow{6}{*}{ VS 20} & \multirow{2}{*}{10} & \multirow{2}{*}{78.1} & $>30 \mathrm{kD}$ & 100 & $106.72 \pm 0.26$ & $-20.5 \pm 0.1$ \\
\hline & & & $<30 \mathrm{kD}$ & 0.0 & n.a. & n.a. \\
\hline & \multirow{2}{*}{30} & \multirow{2}{*}{78.5} & $>30 \mathrm{kD}$ & 98.1 & $108.3 \pm 0.27$ & $-21.2 \pm 0.2$ \\
\hline & & & $<30 \mathrm{kD}$ & 1.9 & $93.93 \pm 0.9$ & $-23.1 \pm 0.5$ \\
\hline & \multirow{2}{*}{80} & \multirow{2}{*}{75.2} & $>30 \mathrm{kD}$ & 98.4 & $108.51 \pm 0.25$ & $-20.9 \pm 0.1$ \\
\hline & & & $<30 \mathrm{kD}$ & 1.6 & $96.3 \pm 0.75$ & $-21.4 \pm 0.6$ \\
\hline \multirow{6}{*}{ VS $15 R$} & \multirow{2}{*}{10} & \multirow{2}{*}{80.0} & $>30 \mathrm{kD}$ & 62.3 & $108.72 \pm 0.28$ & $-19.5 \pm 0.1$ \\
\hline & & & $<30 \mathrm{kD}$ & 37.8 & $107.49 \pm 0.3$ & $-19.5 \pm 0.2$ \\
\hline & \multirow{2}{*}{30} & \multirow{2}{*}{77.8} & $>30 \mathrm{kD}$ & 69.6 & $108.27 \pm 0.31$ & $-18.4 \pm 0.1$ \\
\hline & & & $<30 \mathrm{kD}$ & 30.4 & $108.04 \pm 0.29$ & $-17.9 \pm 0.2$ \\
\hline & \multirow{2}{*}{80} & \multirow{2}{*}{79.3} & $>30 \mathrm{kD}$ & 70.4 & $108.01 \pm 0.27$ & $-21.0 \pm 0.1$ \\
\hline & & & $<30 \mathrm{kD}$ & 29.6 & $108.97 \pm 0.3$ & $-20.0 \pm 0.1$ \\
\hline \multicolumn{7}{|c|}{$2 *$ Ultrafiltration } \\
\hline \multirow{8}{*}{ VS 20} & \multirow{3}{*}{10} & \multirow{3}{*}{90.5} & $>30 \mathrm{kD}$ & 100.0 & $108.41 \pm 0.35$ & $-19.9 \pm 0.3$ \\
\hline & & & $<30 \mathrm{kD}$ & 0.0 & n.a. & n.a. \\
\hline & & & $>30 \mathrm{kD}$ & 92.7 & $109.23 \pm 0.36$ & $-20.3 \pm 0.1$ \\
\hline & \multirow[t]{2}{*}{30} & \multirow[t]{2}{*}{83.8} & $<30 \mathrm{kD}$ & $1: 4.6$ & $1: 99.32 \pm 0.44$ & $1:-23.8 \pm 0.3$ \\
\hline & & & $<50 \mathrm{KD}$ & $2: 2.7$ & 2: n.a. & 2: n.a. \\
\hline & \multirow[t]{3}{*}{80} & \multirow[t]{3}{*}{81.8} & $>30 \mathrm{kD}$ & 95.1 & $111.6 \pm 0.32$ & $-24.6 \pm 0.2$ \\
\hline & & & & $1: 2.6$ & $1: 103.75 \pm 0.57$ & $1:-22.2 \pm 0.1$ \\
\hline & & & $<30 \mathrm{KD}$ & $2: 2.3$ & $2: 103.42 \pm 0.45$ & $2:-25.4 \pm 0.6$ \\
\hline \multirow{9}{*}{ VS $15 R$} & \multirow{4}{*}{10} & \multirow{4}{*}{86.3} & $>30 \mathrm{kD}$ & 61.5 & $107.59 \pm 0.26$ & $-20.7 \pm 0.1$ \\
\hline & & & & $1: 30.9$ & $1: 108.96 \pm 0.29$ & $1:-20.3 \pm 0.1$ \\
\hline & & & $<30 \mathrm{kD}$ & $2: 7.5$ & $2: 106.63 \pm 0.62$ & $2:-20.9 \pm 0.5$ \\
\hline & & & $>30 \mathrm{kD}$ & 61.1 & $108.97 \pm 0.3$ & $-19.0 \pm 0.1$ \\
\hline & \multirow[t]{3}{*}{30} & \multirow[t]{3}{*}{85.7} & $<30 \mathrm{kD}$ & $1: 31.7$ & $1: 109.24 \pm 0.27$ & $1:-21.4 \pm 0.1$ \\
\hline & & & $<30 \mathrm{kD}$ & $2: 7.2$ & $2: 107.92 \pm 0.36$ & $2:-22.4 \pm 0.5$ \\
\hline & & & $>30 \mathrm{kD}$ & 63.8 & $109.56 \pm 0.26$ & $-20.9 \pm 0.1$ \\
\hline & \multirow[t]{2}{*}{80} & \multirow[t]{2}{*}{85.5} & & $1: 27.8$ & $1: 108.74 \pm 0.27$ & $1:-18.2 \pm 0.2$ \\
\hline & & & $<30 \mathrm{KD}$ & $2: 8.4$ & $2: 107.19 \pm 0.31$ & $2:-20.5 \pm 0.7$ \\
\hline
\end{tabular}

${ }^{a}$ Measured at the AMS system simultaneously with the ${ }^{14} \mathrm{C} /{ }^{12} \mathrm{C}$ ratio. This $\delta^{13} \mathrm{C}$ includes the effects of fractionation during graphitization and in the AMS-system and, therefore, cannot be compared with $\delta^{13} \mathrm{C}$ values obtained per mass spectrometer on $\mathrm{CO}_{2}$.

${ }^{14} \mathrm{C}$ measurements of the filtrate $(<30 \mathrm{kD})$ indicate an apparent pollution with fossil carbon, most likely from the membrane material $\left({ }^{14} \mathrm{C}: 0.31-0.5 \mathrm{pMC}\right.$, Hüls et al. 2007) (see Table 1, Figure 2A). Assuming only PES as the source of contamination, the ${ }^{14} \mathrm{C}$ difference between the unfiltered collagen and the filtrate could indicate $12.6 \%$ and $10.4 \%$ contamination for the 30- and 80-mg samples, respectively. This would translate into $30 \mu \mathrm{g}$ and $20 \mu \mathrm{g}$ of carbon from the membrane fibers, respectively. The retentates of the single filtration experiment also show a slight and steady increase in ${ }^{14} \mathrm{C}$ with collagen weight. The ${ }^{14} \mathrm{C}$ difference between $>30 \mathrm{kD}$ and unfiltered collagen is between $2-3 \sigma$ of the measurement uncertainties; the range is $1.8 \mathrm{pMC}, \sim 5 \sigma$.

The ${ }^{14} \mathrm{C}$ measurements for the double filtration experiment show similar features as the single filtration but with increased ${ }^{14} \mathrm{C}$ concentrations in all fractions. As neither glycerin nor filter material 
show these high ${ }^{14} \mathrm{C}$ concentrations, the values for the retentate cannot be explained unless we assume significant age and chemical inhomogeneity in the industrial collagen or batch-to-batch glycerin. The first filtrates from the double filtration can be compared to those from the single filtration. The higher ${ }^{14} \mathrm{C}$ concentrations in these fractions may thus indicate either a smaller contamination with carbon from the filter fibers or an increased contribution of younger carbon from the glycerin or different collagen, like the retentate. The second filtrate of the $80 \mathrm{mg}$-sample showed a ${ }^{14} \mathrm{C}$ concentration well within $1 \sigma$ of first filtrate, indicating no additional contamination.

The retentate $(>30 \mathrm{kD})$ of the double filtration experiment gave ${ }^{14} \mathrm{C}$ concentrations from 108.41 to $111.6 \mathrm{pMC}$ (from 1.0 to $4.2 \mathrm{pMC}, \sim 2.2$ to $9.6 \sigma$ above the unfiltered collagen), increasing with amounts filtrated. If one assumes a large ${ }^{14} \mathrm{C}$ inhomogeneity in this industrial collagen, the results could be explained by removal of smaller proteins with a lower ${ }^{14} \mathrm{C}$ content from larger proteins with a higher ${ }^{14} \mathrm{C}$ content. However, an increasingly effective UF in the larger-sized samples is difficult to accept since the opposite would be expected (higher filtering efficiency with less material to be filtered). On the other hand, if the steady increase of ${ }^{14} \mathrm{C}$ with sample size was caused by enhanced contamination with carbon from glycerin due to the double filtration, the ${ }^{14} \mathrm{C}$ concentration of the glycerin on these filters must have been much higher than indicated by the ${ }^{14} \mathrm{C}$ measurements of the cleaning waters. Clearly, these rather inconsistent results do not fit a simple model.

\section{VS 15R (Hydrosat)}

The recovery of material after ultrafiltration with the VS $15 \mathrm{R}$ is around $80 \%$. The distribution of material over the $>30 \mathrm{kD}$ and $<30 \mathrm{kD}$ fractions for the VS $15 \mathrm{R}$ ultrafilter is quite different from that for VS 20. Here, 60-70 wt $\%$ of the material stay in the retentate (>30 kD) instead of 90-100 wt $\%$. Both ultrafilters have the same MWCO $(30 \mathrm{kD})$ and thus the question arises which filter is correctly separating the different molecular weights.

The ${ }^{14} \mathrm{C}$ contents of the retentate of the single filtration experiment are slightly higher than but close to the ${ }^{14} \mathrm{C}$ content of the unfiltered collagen (difference for the 10-, 30-, and 80-mg sample is 3,2, and $1.8 \sigma$, respectively) (Figure 2B) and within $1 \sigma$ between each sample. Furthermore, the ${ }^{14} \mathrm{C}$ concentrations of the 30- and 80-mg sample fractions agree well with the measured ${ }^{14} \mathrm{C}$ concentrations of the same fractions filtered with VS $20(\Delta: \leq 0.5 \mathrm{pMC}, \leq 1.4 \sigma)$.

The filtrates of the single filtration experiment with VS $15 \mathrm{R}$ show, in contrast to those of VS $20,{ }^{14} \mathrm{C}$ concentrations close to the ${ }^{14} \mathrm{C}$ of the unfiltered collagen but increasing with sample size. Thus, there is no evidence for a contamination with fossil carbon within the $<30 \mathrm{kD}$ fractions. Instead, increased ${ }^{14} \mathrm{C}$ concentrations seem to indicate a small contribution of younger carbon, which, however, is difficult to prove due to the rather small difference in ${ }^{14} \mathrm{C}$ between glycerin and the collagen.

The ${ }^{14} \mathrm{C}$ measurements of the double filtration experiment also show ${ }^{14} \mathrm{C}$ values close to or slightly above the ${ }^{14} \mathrm{C}$ concentration of the unfiltered collagen. A steady increase in ${ }^{14} \mathrm{C}$ with sample size for the retentate seems to indicate admixture of younger carbon as was seen in the single filtration experiment.

To what extent the results of the filtration experiments with the industrial collagen are transferable to bone collagen extracted in the laboratory is uncertain; thus, identical tests were done on extracted modern bone collagen.

\section{Modern Bovine Bone Collagen (KIA 30242)}

The results for the single and double ultrafiltration experiments using VS 20 and VS 15R are summarized in Table 2 and illustrated in Figure 3. 
Table $2{ }^{14} \mathrm{C}$ measurements of modern bovine bone collagen of KIA $30242\left({ }^{14} \mathrm{C}: 106.21 \pm 0.29 \mathrm{pMC}\right.$, $\left.\delta^{13} \mathrm{C}:-13.45 \pm 0.17 \% \circ\right)$.

\begin{tabular}{|c|c|c|c|c|c|c|}
\hline Membrane & $\begin{array}{l}\text { Weight } \\
(\mathrm{mg})\end{array}$ & $\begin{array}{l}\text { Recovery } \\
(\%)\end{array}$ & size & $\mathrm{wt} \%$ & $\mathrm{pMC}$ & $\delta^{13} \mathrm{C}(\% \circ)^{\mathrm{a}}$ \\
\hline \multicolumn{7}{|c|}{$1 *$ Ultrafiltration } \\
\hline \multirow{6}{*}{ VS 20} & \multirow{2}{*}{10} & \multirow{2}{*}{95.6} & $>30 \mathrm{kD}$ & 92.8 & $105.19 \pm 0.36$ & $-14.3 \pm 0.2$ \\
\hline & & & $<30 \mathrm{kD}$ & 7.2 & $94.91 \pm 0.58$ & $-14.7 \pm 0.3$ \\
\hline & \multirow{2}{*}{30} & \multirow{2}{*}{99.7} & $>30 \mathrm{kD}$ & 89.0 & $105.55 \pm 0.33$ & $-13.5 \pm 0.1$ \\
\hline & & & $<30 \mathrm{kD}$ & 11.0 & $100.20 \pm 0.32$ & $-15.0 \pm 0.2$ \\
\hline & \multirow{2}{*}{80} & \multirow{2}{*}{91.4} & $>30 \mathrm{kD}$ & 92.9 & $106.33 \pm 0.41$ & $-12.1 \pm 0.2$ \\
\hline & & & $<30 \mathrm{kD}$ & 7.1 & $101.51 \pm 0.31$ & $-12.4 \pm 0-3$ \\
\hline \multirow{6}{*}{ VS $15 R$} & \multirow{2}{*}{10} & \multirow{2}{*}{91.4} & $>30 \mathrm{kD}$ & 47.5 & $105.06 \pm 0.43$ & $-14.6 \pm 0.2$ \\
\hline & & & $<30 \mathrm{kD}$ & 52.5 & $106.04 \pm 0.33$ & $-11.9 \pm 0.2$ \\
\hline & \multirow{2}{*}{30} & \multirow{2}{*}{108.8} & $>30 \mathrm{kD}$ & 20.8 & $105.13 \pm 0.33$ & $-12.2 \pm 0.2$ \\
\hline & & & $<30 \mathrm{kD}$ & 79.2 & $107.94 \pm 0.36$ & $-14.5 \pm 0.2$ \\
\hline & \multirow{2}{*}{80} & \multirow{2}{*}{98.7} & $>30 \mathrm{kD}$ & 30.7 & $105.75 \pm 0.34$ & $-13.5 \pm 0.2$ \\
\hline & & & $<30 \mathrm{kD}$ & 69.3 & $105.66 \pm 0.28$ & $-13.6 \pm 0.1$ \\
\hline \multicolumn{7}{|c|}{$2 *$ Ultrafiltration } \\
\hline \multirow{7}{*}{ VS 20} & \multirow[b]{2}{*}{10} & \multirow[b]{2}{*}{71.6} & $>30 \mathrm{kD}$ & 88.0 & $105.98 \pm 0.29$ & $-13.2 \pm 0.2$ \\
\hline & & & $<30 \mathrm{kD}$ & 1: 4.0 & n.a & n.a. \\
\hline & \multirow{3}{*}{30} & \multirow{3}{*}{92.4} & $>30 \mathrm{kD}$ & 98.6 & $105.39 \pm 0.29$ & $-13.5 \pm 0.1$ \\
\hline & & & $<30 \mathrm{kD}$ & 1: 1.4 & n.a. & n.a. \\
\hline & & & & 2: 0.0 & & \\
\hline & \multirow{2}{*}{80} & \multirow{2}{*}{90.3} & $>30 \mathrm{kD}$ & 92.7 & $106.32 \pm 0.30$ & $-13.6 \pm 0.2$ \\
\hline & & & $<30 \mathrm{kD}$ & $\begin{array}{l}1.0 .8 \\
2 \cdot 0.5\end{array}$ & $\begin{array}{l}\text { 1: } 102.16 \pm 0.27 \\
\text { 2: n.a. }\end{array}$ & $\begin{array}{l}1:-13.1 \pm 0.2 \\
\text { 2: n.a. }\end{array}$ \\
\hline \multirow{8}{*}{ VS $15 R$} & \multirow{3}{*}{10} & \multirow{3}{*}{27.2} & $>30 \mathrm{kD}$ & 2.2 & n.a. & n.a. \\
\hline & & & $<30 \mathrm{kD}$ & 1: 92.6 & $1: 105.36 \pm 0.37$ & $1:-11.1 \pm 0.2$ \\
\hline & & & $\angle 30 \mathrm{KD}$ & 2: 5.1 & 2: n.a. & 2: n.a. \\
\hline & \multirow{3}{*}{30} & \multirow{3}{*}{94.5} & $>30 \mathrm{kD}$ & 14.7 & n.a. & n.a. \\
\hline & & & $<30 \mathrm{kD}$ & $1: 82.2$ & $1: 106.51 \pm 0.31$ & $1:-14.1 \pm 0.2$ \\
\hline & & & $30 \mathrm{KD}$ & 2: 3.1 & $2: 105.39 \pm 0.46$ & $2:-17.0 \pm 0.2$ \\
\hline & \multirow[b]{2}{*}{80} & \multirow[b]{2}{*}{96.0} & $>30 \mathrm{kD}$ & 27.3 & $105.12 \pm 0.32$ & $-12.7 \pm 0.2$ \\
\hline & & & $<30 \mathrm{kD}$ & 1: 66.3 & 1: $106.9 \pm 0.30$ & $1:-13.9 \pm 0.1$ \\
\hline
\end{tabular}

${ }^{a}$ Measured at the AMS system simultaneously with the ${ }^{14} \mathrm{C} /{ }^{12} \mathrm{C}$ ratio. This $\delta^{13} \mathrm{C}$ includes the effects of fractionation during graphitization and in the AMS-system and, therefore, cannot be compared with $\delta^{13} \mathrm{C}$ values obtained per mass spectrometer on $\mathrm{CO}_{2}$.

\section{VS 20 (PES)}

The recovery of the single and double filtration is $>90 \%$, except for the 10-mg double filtration, where only $71 \%$ was recovered (Table 2). Whether the latter is an outlier is as yet unknown. The fraction retained on the filter $(>30 \mathrm{kD})$ is around $90 \mathrm{wt} \%$, similar to the observations made with KIA 29425 and the VS 20 filter.

The filtrates of the single filtration experiment again show significantly depleted ${ }^{14} \mathrm{C}$ values, indicating a contamination with fossil carbon from membrane material. Since this is also seen in the filtration experiments with the industrial collagen, it may be characteristic for this membrane type. The 


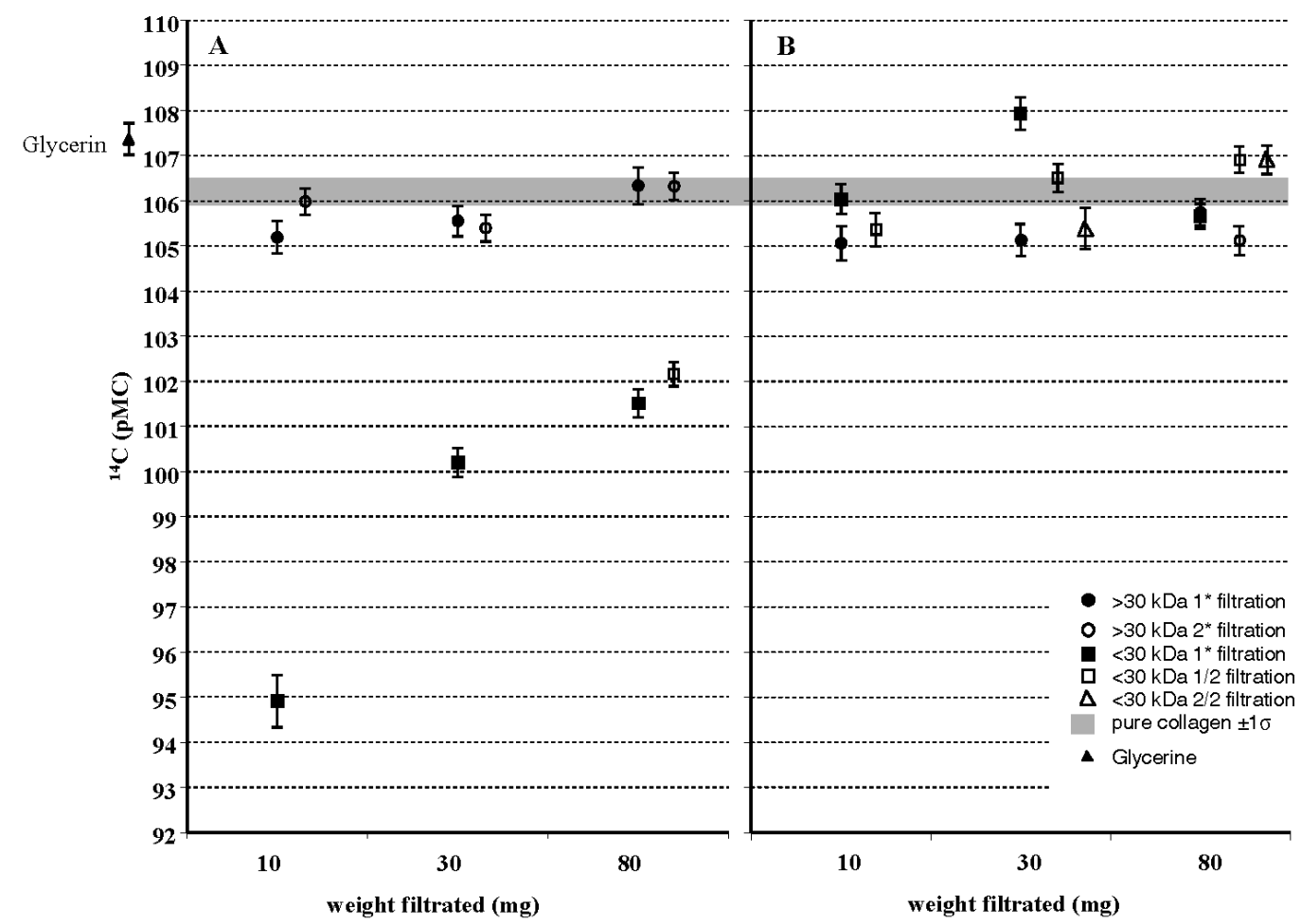

Figure 3 Ultrafiltration of modern bovine bone collagen (KIA 30242): A) Vivaspin 20 (PES); B) Vivaspin 15R (Hydrosat).

amount of old carbon contamination needed to produce the 10-, 30-, and 80-mg filtrate ages is $11 \%$ $(34 \mu \mathrm{g} \mathrm{C}), 6 \%(80 \mu \mathrm{g} \mathrm{C})$, and 5\% (110 $\mu \mathrm{g} \mathrm{C})$, respectively.

The retentates of the 10- and 30-mg samples show ${ }^{14} \mathrm{C}$ concentrations slightly below the ${ }^{14} \mathrm{C}$ content of the unfiltered collagen $(\Delta \sim \leq 1 \mathrm{pMC}, \leq 2.2 \sigma)$. The retentate of the $80-\mathrm{mg}$ sample gave a ${ }^{14} \mathrm{C}$ concentration very similar to that of the unfiltered collagen. These ${ }^{14} \mathrm{C}$ results therefore do not indicate a significant contamination with young carbon from glycerin. A contamination with fossil carbon for the smaller samples ( 10 and $30 \mathrm{mg}$ ) cannot be excluded, but would be on the order of $<1 \%$ ( $<40$ $\mu \mathrm{g} \mathrm{C}$ ). This is clearly opposite to the results obtained with the industrial collagen (KIA 29425), which suggest a contamination with younger carbon.

The fractions of the double filtration experiment show ${ }^{14} \mathrm{C}$ concentrations close to or even within the measurement uncertainties of the respective fractions of the single filtration, indicating no additional contamination with exogenous carbon for the retentate.

\section{VS 15R (Hydrosat)}

The recovery of material after the single and double ultrafiltration is $>90 \%$, except for the $10-\mathrm{mg}$ double filtration, where only $27.2 \%$ was recovered (Table 2 ). This low recovery and a recovery $>100 \%$ for the $30-\mathrm{mg}$ sample in the single filtration may be attributable to weighing errors. The retained $>30 \mathrm{kD}$ fraction is about 48,21 , and $31 \mathrm{wt} \%$ for the single filtration of the 10-, 30-, and 80$\mathrm{mg}$ sample, respectively. This is somewhat less than the 60-70\% obtained with the pig skin collagen for VS 15R and much less the than fraction retained on the VS 20 filters. For the double filtration experiment, the amount of the retained $>30 \mathrm{kD}$ fraction decreased further down to $15 \%$ (30-mg sam- 
ple) and 27\% (80-mg sample). It is obvious that this VS $15 \mathrm{R}$ ultrafilter membrane passes more than the PES membrane.

The retentates $\left(>30 \mathrm{kD}\right.$ ) of the $10-, 30-$, and $80-\mathrm{mg}$ single filtration samples show ${ }^{14} \mathrm{C}$ concentrations slightly lower than the unfiltered collagen $(\Delta \leq 1.15 \mathrm{pMC}, \leq 2.5 \sigma)$ (Figure 4$)$. The ${ }^{14} \mathrm{C}$ concentration measured in the $30-\mathrm{mg}$ sample does not indicate a contamination of the retentate with young carbon as could result from the use of an incompletely cleaned filter (below).

All ${ }^{14} \mathrm{C}$ concentrations of the retentate agree well with the measurements obtained with the VS 20 filter. This result fits into the concept of a homogeneous ${ }^{14} \mathrm{C}$ concentration of our sample KIA 30242. Any significant decrease in ${ }^{14} \mathrm{C}$ of the respective ultrafiltration fractions is thus evidence for an old contamination, which could be inferred to be about 1\% (10- and 30-mg sample; 20 and 30 $\mu \mathrm{g} \mathrm{C}$, respectively) and $0.6 \%$ (80-mg sample; $\sim 60 \mu \mathrm{g} \mathrm{C}$ ). This is clearly different from what is observed with the same membrane in the filtration of the pig skin collagen (KIA 29425, see above), where a contamination with young carbon was suggested.

The filtrates of the 10- and 80-mg samples of the single filtration experiment gave ${ }^{14} \mathrm{C}$ concentrations close to the original unfiltered collagen $(\Delta: \leq 0.6 \mathrm{pMC}, \leq 1.5 \sigma)$. The filtrate of the $30-\mathrm{mg}$ single filtration gave a higher ${ }^{14} \mathrm{C}$ concentration indicating a contamination with young carbon. This agrees with the assumption of the use of an insufficiently cleaned filter as cause of a recovery of more than $100 \%$ (Table 2), but not with the ${ }^{14} \mathrm{C}$ in the retentate.

The double filtration experiment gave enough material for ${ }^{14} \mathrm{C}$ measurements for all three 1 st filtrates and for the 2 nd filtrates of the 30 - and $80-\mathrm{mg}$ samples. The ${ }^{14} \mathrm{C}$ concentrations scatter around the value of the unfiltered collagen (from $-0.85 \mathrm{pMC}, \sim 1.8 \sigma$, to $+0.71 \mathrm{pMC}, \sim 1.7 \sigma$ ) and thus do not indicate any statistically significant contamination.

\section{Radiocarbon Measurements on Fossil Ultrafiltered Collagen}

Ultrafiltration experiments with modern collagen have clear limitations regarding the assessment of a contamination with young carbon. We therefore tested the ultrafiltration with collagen from 2 different fossil bones of Paleolithic age, extracted in the Leibniz Laboratory.

\section{KIA 31556}

The collagen content of this sample, inferred from the amount of extracted gelatin, is about $11 \mathrm{wt} \%$. In this respect, this sample should be considered well preserved. The ${ }^{14} \mathrm{C}$ concentration of the collagen is $0.52 \pm 0.05 \mathrm{pMC}\left(\delta^{13} \mathrm{C}:-18.93 \pm 0.19 \%\right.$ o), which converts to a conventional ${ }^{14} \mathrm{C}$ age of $42,210+840 /-760 \mathrm{yr}$ BP. This compares well to an earlier measurement of the same bone in 2000 giving $0.51 \pm 0.04 \mathrm{pMC}$ and an age of $42,410+670 /-620 \mathrm{yr} \mathrm{BP}$ and confirms the reproducibility and reliability of the result. The non-soluble organic bone rest, retained on the $0.45-\mu \mathrm{g}$ silver filter, was small with respect to the collagen and too small for a reliable ${ }^{14} \mathrm{C}$ measurement. Dissolved collagen was filtered with the VS 20 and the VS $15 R$ ultrafilters. The results for the ${ }^{14} \mathrm{C}$ measurements on the ultrafiltration fractions from VS 20 and VS 15R filters are shown in Table 3 and Figure 4 . The recovery of material after ultrafiltration is $76 \%$ for filtration with VS 20 and $96 \%$ for filtration with VS $15 \mathrm{R}$. The VS 20 filter retains $\sim 92 \mathrm{wt} \%$ in the $>30 \mathrm{kD}$ fraction, VS $15 \mathrm{R}$ only $\sim 43 \mathrm{wt} \%$.

All measured ${ }^{14} \mathrm{C}$ concentrations are higher than the ${ }^{14} \mathrm{C}$ concentration of the unfiltered collagen $(\Delta$ : $0.2-0.3 \mathrm{pMC}, 2-3 \sigma)$. The ${ }^{14} \mathrm{C}$ concentrations of the retentate and the filtrate, filtered with VS 20 and VS $15 R$, are comparable within the $2-\sigma$ measurement uncertainty. From the filtration experiments with the modern collagen, a contamination with fossil C from the VS 20 filter membrane is known. 
Table $3{ }^{14} \mathrm{C}$ measurements of fossil collagen.

\begin{tabular}{|c|c|c|c|c|c|c|c|c|}
\hline $\begin{array}{l}\text { Lab ID/ } \\
{ }^{14} \mathrm{C} \\
\text { Age } \\
{ }^{13} \mathrm{C}\end{array}$ & $\begin{array}{l}\text { Mem- } \\
\text { brane }\end{array}$ & $\begin{array}{l}\text { Weight } \\
(\mathrm{mg})\end{array}$ & $\begin{array}{l}\text { Reco- } \\
\text { very } \\
(\%)\end{array}$ & $\begin{array}{l}\text { Size } \\
(\mathrm{kD})\end{array}$ & $\mathrm{wt} \%$ & $\mathrm{pMC}$ & ${ }^{14} \mathrm{C}$ age $\mathrm{BP}$ & $\delta^{13} \mathrm{C}(\% o)^{\mathrm{a}}$ \\
\hline $\begin{array}{l}\text { KIA } 31556 / \\
0.52 \pm 0.05 \mathrm{pMC} \\
42,210+840 /-760 \mathrm{BP} \\
-18.93 \pm 0.19 \% \text { o }\end{array}$ & VS $15 R$ & 50 & 75.9 & $\begin{array}{l}>30 \\
<30 \\
>30 \\
<30\end{array}$ & $\begin{array}{r}91.5 \\
8.5 \\
43.1 \\
56.9\end{array}$ & $\begin{array}{l}0.69 \pm 0.05 \\
0.81 \pm 0.11 \\
0.74 \pm 0.05 \\
0.74 \pm 0.05\end{array}$ & $\begin{array}{l}39,990+630 /-580 \\
38,650+1220 /-1060 \\
39,470+620 /-570 \\
39,380+580 /-540\end{array}$ & $\begin{array}{l}-22.9 \pm 0.2 \\
-22.4 \pm 0.1 \\
-22.3 \pm 0.2 \\
-22.6 \pm 0.2\end{array}$ \\
\hline $\begin{array}{l}\text { KIA } 31557 / \\
0.12 \pm 0.05 \mathrm{pMC} \\
54,350 \pm 4400 /-2830 \mathrm{BP} \\
-20.80 \pm 0.28 \% \text { o }\end{array}$ & VS $15 R$ & 50 & 94.96 & $\begin{array}{l}>30 \\
<30 \\
>30 \\
<30\end{array}$ & $\begin{array}{l}86.2 \\
13.8 \\
33.3 \\
66.7 \\
\end{array}$ & $\begin{array}{l}0.18 \pm 0.05 \\
0.40 \pm 0.07 \\
0.46 \pm 0.05 \\
0.27 \pm 0.05\end{array}$ & $\begin{array}{l}50,970+2680 /-2010 \\
44,390+1430 /-1220 \\
43,190+960 /-860 \\
47,610+1710 /-1410 \\
\end{array}$ & $\begin{array}{l}-18.3 \pm 0.2 \\
-20.8 \pm 0.1 \\
-19.8 \pm 0.2 \\
-18.9 \pm 0.2 \\
\end{array}$ \\
\hline
\end{tabular}

${ }^{\text {a }}$ Measured at the AMS system simultaneously with the ${ }^{14} \mathrm{C} /{ }^{12} \mathrm{C}$ ratio. This $\delta^{13} \mathrm{C}$ includes the effects of fractionation during graphitization and in the AMS system and, therefore, cannot be compared with $\delta^{13} \mathrm{C}$ values obtained per mass spectrometer on $\mathrm{CO}_{2}$.
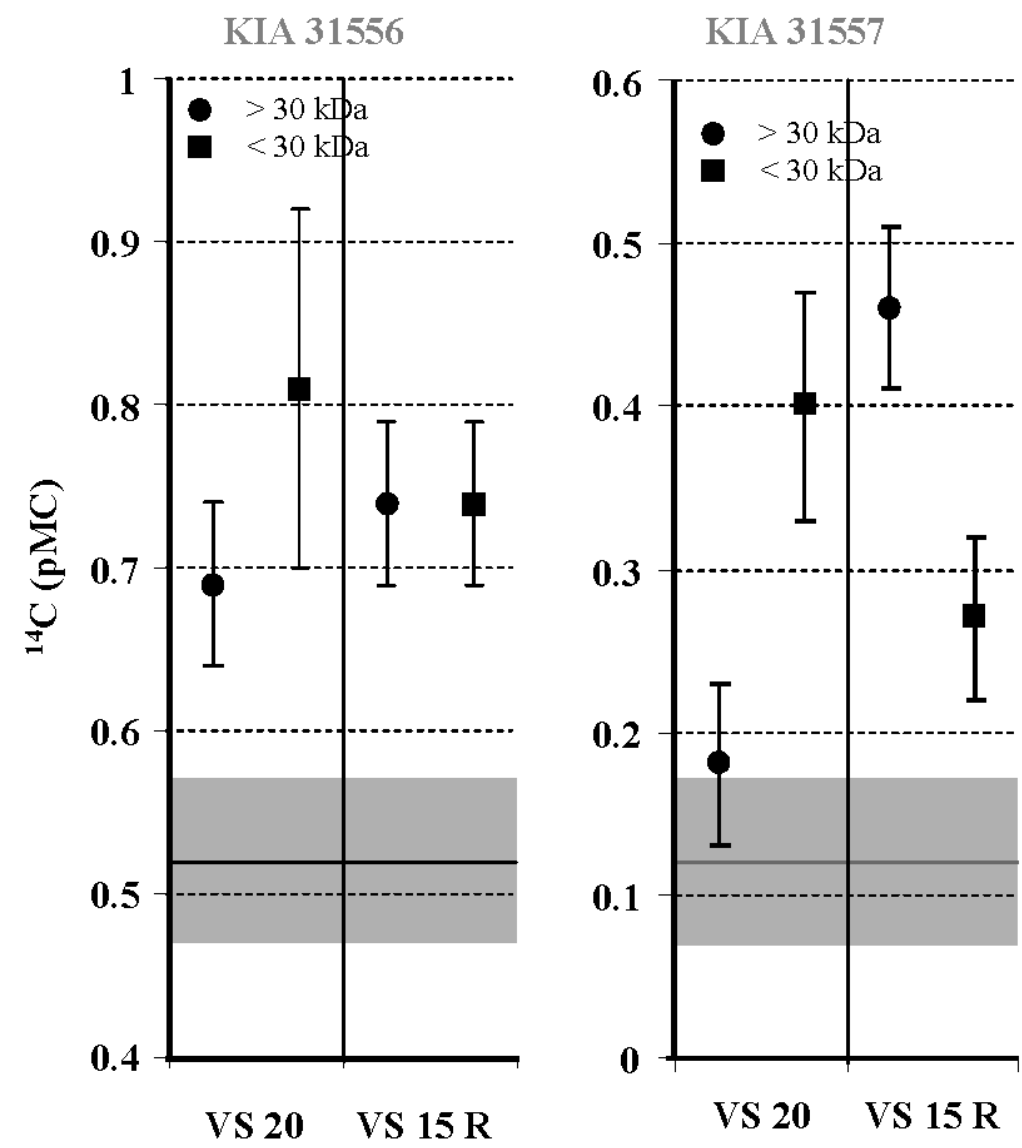

Figure 4 Ultrafiltration of fossil bone collagen. Left side: KIA 31556; right side: KIA 31557.

However, the ${ }^{14} \mathrm{C}$ concentrations of the VS 20 membrane and the unfiltered collagen are similar, so this is not seen here. The results thus may be best explained by a small contamination with younger 
carbon in both ultrafiltration fractions, as was observed in earlier work (Hüls et al. 2007). If so, a contamination of about $0.2 \%$, equivalent to about $30-40 \mu \mathrm{g}$ of recent carbon, would be sufficient to explain the results. Lacking unambiguous confirmation about a presence of remaining glycerin in the filter membranes, the source of such a contamination remains unknown.

\section{KIA 31557}

The collagen content of this sample is about $7.8 \mathrm{wt} \%$. The ${ }^{14} \mathrm{C}$ concentration of the collagen was measured to $0.12 \pm 0.05 \mathrm{pMC}\left(\delta^{13} \mathrm{C}:-20.80 \pm 0.28 \%\right.$, conventional ${ }^{14} \mathrm{C}$ age $54350+4400 /-2830 \mathrm{yr}$ BP). An earlier measurement on the same bone in 2000 gave $0.31 \pm 0.05 \mathrm{pMC}$ and an age of 46,380 $+1360 /-1170 \mathrm{yr}$ BP. The lower ${ }^{14} \mathrm{C}$ content of the recent preparation may reflect the $\mathrm{NaOH}$ cleaning step, which had not yet been put into routine in 2000 . The non-soluble organic bone rest gave a ${ }^{14} \mathrm{C}$ of $2.28 \pm 0.37 \mathrm{pMC}$, indicating a significant contribution of young foreign carbon to this small fraction and to the original organic material of the bone. In this respect, we would expect an older ${ }^{14} \mathrm{C}$ age for the retentate compared to the unfiltered collagen, if residual contamination was still present in the gelatin filtered over $0.45 \mu \mathrm{m}$, and was linked to small-sized molecules.

The recovery of material after ultrafiltration is $88 \%$ for VS 20 and $95 \%$ for filtration with VS 15R, similar to KIA 31556 . The VS 20 filter retains $\sim 86 \mathrm{wt} \%$ in the $>30 \mathrm{kD}$ fraction and VS $15 \mathrm{R} \sim 33 \mathrm{wt} \%$. This difference in retention is similar to that observed for KIA 31556 and the young bovine collagen KIA 30242, also prepared in-house.

The collagen of the retentate, filtered with VS 20 , gave a ${ }^{14} \mathrm{C}$ concentration close to the concentration of the unfiltered collagen $\left(\Delta: 0.06 \mathrm{pMC}, 0.8 \sigma\right.$ ) (see Table 3, Figure 4). The ${ }^{14} \mathrm{C}$ concentration in the filtrate is higher $(0.28 \pm 0.09 \mathrm{pMC}, \sim 3.2 \sigma)$, suggesting enrichment of a younger contaminant (cleaning of the sample or filter contaminant). A mass balance calculated ${ }^{14} \mathrm{C}$ concentration $\left({ }^{14} \mathrm{C}_{\text {calc }}=a \times{ }^{14} \mathrm{C}_{>30 \mathrm{kD}}+b \times{ }^{14} \mathrm{C}_{<30 \mathrm{kD}}\right.$; where $a$ and $b$ are relative amounts of UF fractions) is, due to the small size of the filtrate, about $0.22 \mathrm{pMC}$, close to the unfiltered collagen. These results thus do not show a statistically significant contamination with foreign carbon from the filter. Yet the results do suggest an increase in ${ }^{14} \mathrm{C}$ with increased processing

The filtration experiment with VS $15 \mathrm{R}$ gives a significantly higher ${ }^{14} \mathrm{C}$ concentration in the smaller $>30 \mathrm{kD}$ fraction $(\Delta: 0.34 \mathrm{pMC}, 4.8 \sigma)$. The ${ }^{14} \mathrm{C}$ concentration in the larger $(66.7 \%)$ filtrate is close to that of the unfiltered collagen $(\Delta: 0.15 \mathrm{pMC}, 2 \sigma)$. These results appear at odds with earlier findings, but may reflect statistical scatter for small numbers in the absence of significant contamination.

\section{CONCLUSIONS}

The potential of ultrafilters to introduce organic carbon, especially from the glycerin coating of the filter membranes, into filtered samples is a problem that still has not been completely resolved. Carbon measurements of filtered ultra-pure water during and after the recommended cleaning procedure suggest an almost complete removal of the glycerin coating the filter membranes. SEM pictures still show the presence of film remnants on and within the fibrous cleaned membranes. However, EDX analysis on the VS 20 filter membrane indicates these flakes may be polyethersulfone.

The 2 filter types, VS 20 (polyethersulfone) and VS 15R (regenerated cellulose), both show a good recovery of the filtered collagen (values-with 1 exception-in the range from 70 to 100\%). The 2 filter types with a rated molecular weight cut-off of $30 \mathrm{kD}$ show, however, a quite different mass separation as documented by different amounts of material retained above and passed through the filter. VS 20 retained $85-100 \mathrm{wt} \%$ of the sample material above the filter, with a slightly higher retention for the pig collagen (92.7-100\%). The VS 15R filter retained $60-70 \mathrm{wt} \%$ of the pig col- 
lagen but $20-50 \mathrm{wt} \%$ of the modern and fossil bone collagen. One possible explanation for this difference could be the influence of electrostatic forces between protein and polyethersulfone membrane, depending on $\mathrm{pH}$ and protein ionization (e.g. Wang and Rogers 2005; Burns and Zydney 1999), and vice versa.

This raises several questions: (i) What is the true molecular weight cut-off of the different filters for gelatin, polypeptides, and contaminants?; (ii) How is the filtration property of the different ultrafilters influenced by the cleaning procedure and (iii) by the filtering conditions like $\mathrm{pH}$ and temperature?; and (iv) How dependent is the size distribution of the collagen hydrolysis products on the collagen and the $\mathrm{pH}$, temperature, and time of the hydrolysis.

If the separation of the retentate and the filtrate by the VS $15 \mathrm{R}$ filter is correct, the modern collagen sample apparently contains a large fraction of small proteins $(<30 \mathrm{kD})$, which would indicate a larger degradation of bone protein due to gelatinization $>60^{\circ} \mathrm{C}$ (Brown et al. 1988).

${ }^{14} \mathrm{C}$ measurements with modern collagen give for VS $15 \mathrm{R}$ no clear evidence for contamination with either young or old carbon for both fractions ( $>30 \mathrm{kD}$ and $<30 \mathrm{kD}$ ). The VS 20 filter shows a clear contamination with fossil carbon, possibly from the filter, in the $<30 \mathrm{kD}$ fraction. ${ }^{14} \mathrm{C}$ concentrations measured on ultrafiltered fossil collagen indicate, as in previous studies (e.g. Hüls et al. 2007), a small contamination with younger carbon.

The question whether ultrafiltration is a boon or bane for the reliable dating of bones can thus not yet be answered conclusively. Despite its potential advantages for cleaning heavily contaminated bone samples, its risks need to be better understood before ultrafiltration should become a routine element of bone ${ }^{14} \mathrm{C}$ dating.

\section{ACKNOWLEDGMENTS}

We thank the Leibniz team for high quality sample preparation and AMS analyses. We appreciate the comments of 2 anonymous reviewers which helped to improve the manuscript.

\section{REFERENCES}

Brock F, Bronk Ramsey C, Higham TFG. 2007. Quality assurance of ultrafiltered bone dating. Radiocarbon 49(2):187-92.

Bronk Ramsey C, Higham T, Bowles A, Hedges R. 2004. Improvements to the pretreatment of bone at Oxford. Radiocarbon 46(1):155-63.

Brown TA, Nelson DE, Vogel JS, Southon JR 1988. Improved collagen extraction by modified Longin method. Radiocarbon 30(2):171-7.

Burns DB, Zydney AL. 1999. Effect of solution pH on protein transport through ultrafiltration membranes. Biotechnology and Bioengineering 64(1):27-37.

Gosh R. 2003. Protein Bioseparation Using Ultrafiltration: Theory, Applications and New Developments. London: Imperial College Press. 166 p.

Grootes PM, Nadeau M-J, Rieck A. 2004. ${ }^{14}$ C-AMS at the Leibniz-Labor: radiometric dating and isotope research. Nuclear Instruments and Methods in Physics Research B 223-224:55-61.

Higham T, Bronk Ramsey C, Karavanić I, Smith FH, Trinkaus E. 2006. Revised direct radiocarbon dating of the Vindija $\mathrm{G}_{1}$ Upper Paleolithic Neandertals. Proceedings of the National Academy of Science (USA) 103(3):553-7.

Hüls CM, Grootes PM, Nadeau M-J. 2007. How clean is ultra filtration cleaning of bone collagen? Radiocarbon 49(2):193-200.

Levin I, Kromer B. 2004. The tropospheric ${ }^{14} \mathrm{CO}_{2}$ level in mid-latitudes of the Northern Hemisphere (19592003). Radiocarbon 46(3):1261-72.

Longin R. 1970. Extraction du collagène des os fossiles pour leur datation par la méthode du carbone $14[\mathrm{PhD}$ dissertation]. Université de Lyon.

Mellars P. 2006. A new radiocarbon revolution and the dispersal of modern humans in Eurasia. Nature 439(7079):931-5.

Nadeau M-J, Schleicher M., Grootes PM, Erlenkeuser H, Gottdang A, Mous DJW, Sarnthein JM, Willkomm H. 1997. The Leibniz-Labor AMS facility at the Christian-Albrechts-University, Kiel, Germany. Nuclear Instruments and Methods in Physics Research B 123(1-4):22-30. 
Nadeau M-J, Grootes PM, Schleicher M, Hasselberg P, Rieck A, Bitterling M. 1998. Sample throughput and data quality at the Leibniz-Labor AMS Facility. $R a$ diocarbon 40(1):239-45.

van Klinken GJ, Hedges REM. 1995. Experiments on collagen-humic interactions: speed of humic uptake, and effects of diverse chemical treatments. Journal of Archaeological Science 22(2):263-70.

van Klinken GJ, Mook WG. 1990. Preparative high-per- formance liquid chromatographic separation of individual amino acids derived from fossil bone collagen. Radiocarbon 32(2):155-64.

Wang Y, Rodgers VGJ. 2005. The effect of electrostatic properties in binary protein ultrafiltration. In: The American Institute of Chemical Engineers, 2005 Annual Meeting, Topical 8 Bioseparations, Abstract \#465. Membrane-Based Bioseparations. 